\title{
THE SCHOOL OF ECOLOGICAL CHEMISTRY FOUNDED BY ACADEMICIAN GHEORGHE DUCA
}

\author{
Tudor Lupascu ${ }^{a^{*}}$, Maria Gonta ${ }^{\mathrm{b}}$, Viorica Gladchi ${ }^{\mathrm{b}}$ \\ ${ }^{a}$ Institute of Chemistry of ASM, 3 Academiei str., MD-2028 Chişinău, R. Moldova \\ ${ }^{b}$ State University of Moldova, 60 A. Mateevici str., MD-2009 Chişinău, R. Moldova \\ Email: lupascut@gmail.com, phone: (37322) 735490
}

\begin{abstract}
This review details the most important achievements in the field of ecological chemistry and environmental protection, obtained at the State University of Moldova and Institute of Chemistry of the Academy of Sciences of Moldova. The main research directions are described, as well as main scientific laboratories and centres of these two institutions.
\end{abstract}

Keywords: ecological chemistry, redox catalysis, activated carbons, environmental pollution.

Scientific research in the field of ecological chemistry and physico-chemical mechanisms which occur in the environment were initiated in the frames of the Department of Physical Chemistry, by prof. A. Sîciov. A very important part of scientific research performed in the field of oxidation-reduction catalytic processes was carried out in the frameworks of the Physical Chemistry department, by prof. V. Isac. Intensification of this research field led to the formation, in 1988, of the scientific laboratory Applied and Ecological Chemistry, one the initiative of acad. Gh. Duca. In the 80 's, under the direction of prof. A. Sîciov, research was performed in the field of chemical and photochemical oxidation-reduction processes, related to transformations in model and real systems of hydroxy acids, phenols, several pesticides; also, the role of hydrogen peroxide and variable valence metal ions in these processes was determined (A. Sîciov, Gh. Duca, M. Gonța, L. Romanciuc).

On the basis of the obtained experimental results, the monography "Catalytic reactions and environmental protection" was edited [3]. Beside the study of processes of transformation of various compounds in aquatic systems, investigations concerning transformations of nitrites, nitrates and formation of N-nitrosamines were initiated in the early 80's (Gh. Duca, M. Gonţa).

The research directions in the frames of the SL of Applied and Ecological Chemistry were always up-to-date. However, in order to widen the possibility of solving environmental problems, training of highly qualified specialists in the field of ecological chemistry was necessary.

Therefore, on the initiative of acad. Gh. Duca, the Department of Industrial and Ecological Chemistry was founded at the State University of Moldova, in the frames of the Faculty of Chemistry and Chemical Technology. This was the first department in the country, in the field of ecological chemistry and environmental protection, which started preparing students and PhD's at the specialty Environmental protection and rational utilization of natural resources.

The first manual of ecological chemistry was edited in 1994, and subsequently translated in three languages [1]. In 1996, the Centre of scientific researches in Applied and Ecological Chemistry (CSRAEC) was founded, comprising 4 scientific laboratories. Research performed at the department, in the frames of CSRAEC laboratories, was directed towards Chemistry and Technology of Industrial Processes and Treatment of Water and Wastes and was crowned with important elaborations, such as:

- Oxidation theory of waters chemical self purification process and of seasonal dynamics of natural waters redox state

- Theory of fluid reactors of nitrogen compounds transformation using support-immobilized microorganisms

- Theory of the redox state of the environment

- Methods of physico-chemical and biochemical treatment of solid waste and waste waters

- Methods of inhibition of formation of N-nitrosamines using reductons

- Mechanisms of catalytic and photochemical oxidation of organic compounds with oxygen, hydrogen peroxide and free radicals.

Scientific Laboratory „Ecological chemistry of aquatic systems” (PhD V. Gladchi, PhD N. Goreacev, PhD L. Romanciuc)

One of the most important particularities of the environment consists in the fact that changes usually occur at rates exceeding those of development of control and prognostication methods. Often, ecologically unfavourable phenomena are only ascertained, without the possibility of preventing them. In order to reduce this discrepancy, is required a new method of treating the processes which happen in the environment, taking into account that this is a chemical-physical-biological whole and unique system. Therefore, the necessity of knowing the chemical, physico- 
chemical and biochemical processes of interaction between living organism and the environment, appears to be crucial in order to provide a qualified description and management of the equilibrium state of ecosystems, given the increased anthropogenic activity.

For an adequate estimation of the ecological state of natural waters, various research methods must be used, which include studying physical, chemical and biological processes which occur in aquatic ecosystems. Chemical processes in the aquatic medium, which are related to the oxidation of some compounds, and the reduction of others, occur catalytically or under the influence of solar irradiation. The catalysts in such processes are ions and complex compounds of transition metals, present in natural waters.

Among oxidizing equivalents present in aquatic systems, the most important are the dissolved oxygen and hydrogen peroxide [1,2]. The specifics of these oxidants is their quite low reactivity, thus the majority of them needs to be activated using metal ions, such as copper and iron. Although redox-catalytic processes in aquatic systems are numerous and various, all of them are based on a limited number of typical reactions. The most efficient method of estimating the mechanisms of chemical processes in the aquatic environment, is their modelling, i.e. separate study in laboratory conditions using a certain number of parameters which can be experimentally determined. The study of mechanisms of transformation of various compounds in the frames of these model systems allows explaining the processes which take place in natural ecosystems, and suggests methods of diminution of their pollution.

Transformations of many chemical compounds in the aquatic medium are accompanied by the formation of free radicals which actively participate in processes of chemical self purification of natural waters. The equilibrium of oxidation and reduction processes form a special state of the aquatic medium - the redox state, notion proposed by us in collaboration with Russian scientists [3-6]. It consists in detecting the oxidation and reduction flows, as function of the intensity of oxidation and reduction processes in the aquatic medium. The oxidative state is determined by the presence of hydrogen peroxide, while the reducing state - by the presence of reducing compounds, which can be easily oxidized by $\mathrm{H}_{2} \mathrm{O}_{2}$.

Taking into consideration all mentioned above statements, the necessity of introducing and implementing new methods for characterization of natural waters state and estimation of their self purification capacity is of great importance. Therefore, during several last years, our attention was focused on research of kinetic laws related to chemical and photochemical self purification of aquatic systems, in the presence of increased amounts of various pollutants. Our investigations demonstrated that these processes have an important role in the totality of self purification processes occurring in natural waters $[4,7]$.

Kinetic treatment of laws of chemical self purification process offer a unique opportunity to evidence the parameters which determine chemical transformations of pollutants by their interaction with other elements of the aquatic medium. This treatment doesn't exclude utilization of traditional hydrochemical and biological methods used for ascertaining of natural waters quality and their dynamic characteristics.

For many years, we have collaborated with researchers from the Institute of Chemical Physics of the Academy of Science of Russia, in the field of studying the chemical self purification processes of aquatic medium, including the possible mechanisms of redox-catalytic transformations of pollutants, which involve dissolved oxygen and its active forms - hydrogen peroxide and $\mathrm{OH}$ radicals.

Initially, researches were performed in the frames of various model systems, and further the methods of determination of various kinetic parameters were widely approved for various aquatic objects of the Republic, in order to perform the ecological monitoring of natural waters. Methods of active redox components determination and of their seasonal dynamics in natural waters were elaborated, optimized and implemented: hydrogen peroxide, $\mathrm{OH}$ radicals, inhibition capacity of natural waters towards processing involving $\mathrm{OH}$ radicals. For the first time, these methods were applied for the estimation of the state of rivers Nistru and Prut.

The elaboration of kinetic methods for the complex estimation of the state of environmental aquatic objects is based upon the following fundamental principles.

An important oxidant in the aquatic environment is the dissolved oxygen, which is a quite inert substance in usual conditions. The oxygen cycle in water represents a fundamental factor which assures a normal activity of living organisms, and it is closely linked with other biogeochemical cycles. In the case of dissolved oxygen participation in chemical self purification processes of water, its reduction leads to the formation of several products, which posses high reactivity, and contribute to a more efficient occurrence of these processes.

The presence of hydrogen peroxide in natural waters is very important for self purification processes. It practically represents a carrier of oxidizing equivalents in the aquatic medium, being an intermediate product of reduction of

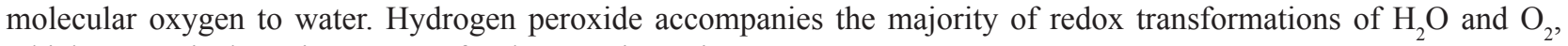
which proves its huge importance for the aquatic environment.

Catalytic activation of $\mathrm{O}_{2}$ and $\mathrm{H}_{2} \mathrm{O}_{2}$ in real conditions may take place if reduced forms of transition metals ions are present in water $-\mathrm{Fe}(\mathrm{II})$ and $\mathrm{Cu}(\mathrm{I})$, which are catalysts for this process. Complex ions of iron and copper interact with $\mathrm{H}_{2} \mathrm{O}_{2}$ to give hydroxyl radicals, which posses a significant chemical and biological activity, as compared to other products of oxygen monoelectronic activation. 
In the case when the penetration of hydrogen peroxide into natural waters is higher than the penetration of reducing agents, the concentration of hydrogen peroxide is higher than the stationary concentration of reductants. In this case, natural waters posses an oxidizing environment. However, if the stationary concentration of reductants is higher than that of $\mathrm{H}_{2} \mathrm{O}_{2}$, a reducing environment is installed, which leads to the diminution of self purification capacity of the aquatic environment. In this case, utilization of titration methods for the determination of redox equivalents will lead to the discovery of reductants instead of the oxidant. The reducing state is temporary, due to the presence in waters of dissolved oxygen, which will trigger the oxidation of all reducing equivalents [3].

The phenomenon of existence and importance of free radicals in natural waters is not widely discussed and studied. It is known [4] that the stationary concentration of $\mathrm{OH}$ radicals, the most active oxidant in natural waters, is quite low $\left(\approx 10^{-15}-10^{-17} \mathrm{M}\right)$, but due to its high reactivity, it plays a very important role in regulating the composition and self purification of the aquatic environment.

The method of determination of the stationary concentration of $\mathrm{OH}$ radicals [7] consists in the determination of the ratio between two kinetic parameters - rate of initiation and effective constant of $\mathrm{OH}$ radicals' disappearance as a result of their interaction with the components of the aquatic medium.

Therefore, application of kinetic parameters, determination of the redox state of natural waters by the hydrogen peroxide content, their inhibition capacity and stationary $\mathrm{OH}$ radicals concentration, estimates the dynamic equilibrium between the oxidizing and reducing equivalents in natural waters, and may serve as an integral parameter of assessing the redox-catalytic balance inside the aquatic reservoir, the intensity of self purification processes involving $\mathrm{OH}$ radicals and to characterize the ecological state of the water reservoir.

The method of application of kinetic parameters conjunctively with traditional hydrological parameters was approved in the Republic of Moldova and is currently applied for the estimation of chemical composition and self purification processes in the waters of the Nistru river [8-10].

Obtained results show that a seasonal change in the redox state is characteristic for the waters of Nistru river. The general tendency for the autumn-spring period is the decrease of hydrogen peroxide concentration and creation of an unstable, or even quasi-reducing state of waters, from the point of view of redox equivalents - of hydrogen peroxide and reductants of peroxidasic type. During summer, the content of hydrogen peroxide increases up to $10^{-6} \mathrm{M}$. However, this increase is characteristic only for the sector Naslavcea-Cosăuți, while hydrogen peroxide is totally absent in the sector Boşerniţa-Dubăsari, downstream the dam.

The decrease of the $\mathrm{H}_{2} \mathrm{O}_{2}$ concentration during September-November, its insufficiency in March may be explained, on one hand, by the decrease of photosynthetical activity, the predominant role in $\mathrm{H}_{2} \mathrm{O}_{2}$ formation in natural waters being solar radiation (which induces the formation of the superoxide radical anion $\mathrm{O}_{2}^{-}$, the precursor of $\mathrm{H}_{2} \mathrm{O}_{2}$ ). On the other hand, in autumn decreases the temperature of waters, which is one of the physico-chemical parameters which influence the rate of redox-catalytic processes.

The values of registered $\mathrm{H}_{2} \mathrm{O}_{2}$ concentrations are mostly close to $10^{-7} \mathrm{M}$, which is insufficient for an efficient realization of chemical self purification processes in waters. Beside these conclusions, it should be mentioned that processes of chemical self purification involving $\mathrm{OH}$ radicals, occur effectively in the waters of Nistru during summer, which can contribute to the increase of water pollution.

Obtained results evidenced that Nistru river waters continue to be polluted by reducing compounds which decrease the content of hydrogen peroxide in the aquatic reservoir, thus creating conditions for the instauration of a reducing environment of aquatic ecosystems - an unfavourable state for living organisms. The degradation of Nistru waters are due to the increased level of pollution of influents waters, as well as of domestic waters evacuated from riparian localities, and waters accumulated before the Naslavcea and Dubăsari dams.

These scientific results are only the beginning of a series of investigations regarding aquatic objects of the Republic of Moldova, which are now extending on Nistru influents- rivers Răut, Ichel, Bîc and Botna.

The investigations performed up to now, and those that are in progress, confirm that application of kinetic parameters in estimation of the state of aquatic objects represent a necessary addition to traditionally determined hydrochemical parameters. In the case of critical situations of various aquatic objects (perishing of fish, overflowing of huge amounts of pollutants etc.), the application of methods for the determination of hydrogen peroxide in water, of the inhibition capacity and of the stationary concentration of free radicals may become necessary for an immediate response to improve the situation, as well as for prognostication and pollution prevention.

\section{Scientific Laboratory Redox-catalysis in water and foodstuffs}

During last three decades, numerous investigations were performed for hazard assessment of persistent carcinogenic substances, which are harmful for humans. Among the large number of such compounds, N-nitroso compounds (NNC) are of special interest, $80 \%$ of which possess carcinogenic action and induce malign tumours in almost all human and animal organs.

$\mathrm{N}$-nitroso compounds are formed quite easily inside the human body, in foodstuffs and tobacco smoke. The synthesis of these compounds occurs, predominantly, from secondary amines and nitrites or nitrogen oxides. 
Scientific research in the field of carcinogenesis of these compounds, initiated in the 80's, developed in several directions up to date: (i)- monitoring of known NNC sources in the environment and foodstuffs, (ii) - determination of mechanisms of carcinogens formation and (iii)- elaboration of methods for the prevention of appearance and spreading of carcinogenic agents.

Therefore, one of the scientific directions is the Transformation of nitrites, nitrates, formation of $N$-nitroso amines and utilization of inhibitors in redox processes (acad. Gh. Duca, Dr. hab. M. Gonța, PhD I. Stepanov, PhD I. Subotin and PhD D. Porubin).

The study of kinetics and mechanisms of NNA formation on various environmental objects is of great importance for a correct understanding of the negative effects of NNA on living organisms [15]. Elaboration of several methods of inhibition of secondary amines nitrosation leads to the diminution of NNA concentration, which can be formed in vitro as well as in vivo. One of the most important results in this area is the elaboration of methods of inhibition of NNA formation using natural reductons.

The mechanism of inhibition of amines (aliphatic and cyclic) and amides nitrosation, using reductants obtained from secondary winery products $\left(\mathrm{DFH}_{4}\right.$, dimethyl ester of dihydroxyfumaric acid and $\mathrm{DFH}_{3} \mathrm{Na}$ was studied [10]. As a result of computational estimation of model systems used for nitrosation of various substrates with nitrite ions, species concentrations were determined and it was found that the concentration of the nitrosating agent $\mathrm{N}_{2} \mathrm{O}_{3}$ is almost twice greater than the concentration of $\mathrm{NO}^{+}$. Te rate constants were calculated for the process of inhibition of MORF nitrosation using various reductants, obtained from secondary winery products, which may be presented as follows: $\mathrm{k}_{\mathrm{inh}}{ }^{\mathrm{DFH}}=1,8 \mathrm{M}^{-1} \mathrm{~s}^{-1}>\mathrm{k}_{\mathrm{inh}}{ }^{\mathrm{EDMD}}=1,4 \mathrm{M}^{-1} \mathrm{~s}^{-1}>\mathrm{k}_{\mathrm{inh}}{ }^{(+)-C t}=1,01 \mathrm{M}^{-1} \mathrm{~s}^{-1}>\mathrm{k}_{\mathrm{inh}}{ }^{\mathrm{DFH} 3 \mathrm{Na}}=0,74 \mathrm{M}^{-1} \mathrm{~s}^{-1}>\mathrm{k}_{\mathrm{inh}}{ }^{\text {EDMT }}=0,25 \mathrm{M}^{-1} \mathrm{~s}^{-1}$.

It was established that the formation of tobacco specific N-nitroso amines during fermentation is determined by technological processing, tobacco type, and may be inhibited by using dipotassium tartrate [14]. The short duration of the tobacco fermentation process determines a low content of TSNA in cigarettes produced in Moldova, while its sauceing, for longer periods and at higher temperatures, leads to the increase of TSNA in American cigarettes.

Inhibition activity of $\mathrm{DFH}_{4}$ and $\mathrm{DFH}_{3} \mathrm{Na}$ was determined, related to the process of nitrosation of metabolites formed in the gastric juice, at proteolysis of albumin and casein in the presence of various enzymes (pepsin, trypsin, chemotrypsin) and at nitrosation of nornicotine in vivo [16]. Analysis of the content of non-hydrolysed protein substrate showed that sodium hydrogen dihydroxyfumarate, used as an inhibitor of the nitrosation of the formed metabolites, doesn't influence the activity of specific enzymes. It was determined that $\mathrm{DFH}_{3} \mathrm{Na}$ decreases the rate of formation of $\mathrm{MetHb}$ at oxidation of $\mathrm{HBO}_{2}$ with nitrite ions, by decreasing the acceleration factor with the increase of reductons' concentration. The mechanism of action of sodium hydrogen dihydroxyfumarate on the process of oxyhaemoglobin oxidation with nitrite ions, was ascertained, and it was found that it is based on the interaction of the $\mathrm{OH}^{\circ}$ and $\mathrm{HO}_{2}{ }^{\circ}$ radicals.

Using the DPPH-radical and the $\mathrm{ABTS}^{+}$-cation-radical, the antioxidant/antiradical activities were determined for reductons obtained from secondary winery products, and it was found that the antiradical power of $\mathrm{DFH}_{4} \mathrm{and}_{\mathrm{DFH}} \mathrm{Na}$ is comparable to the antiradical power of $(+)$-catechin and quercitin.

Also, research regarding treatment of natural waters from nitrites and nitrates was performed, using electrochemical methods (Gh. Duca, M. Gonța, V. Matveevici and V. Iambarțev), due to the fact that one of the most important source of nitrosation agents in natural waters are the $\mathrm{NO}_{3}^{-}$ions. The main objective of these investigations was to achieve the maximal admissible concentration for nitrite and nitrate ions, during treatment of model systems, as well as natural waters. Results obtained in scientific studies showed that in the case of treatment of natural waters using the electrochemical method with soluble anodes of aluminium, iron and magnesium, the effect of diminution of nitrates and nitrites depends of the $\mathrm{pH}$ value, the intensity of the current and the amount of electricity [11].

Treatment conditions were optimized in order to achieve the MAC for nitrites and nitrates. As opposed to aluminium, the efficiency of treatment with soluble magnesium anodes is higher at a lower electricity amount (180-600 C), and the increase of Q (600-900 C) leads to a maximal efficiency in the case of treatment using soluble aluminium anodes. During electrochemical dissolving of aluminium electrode, additional monovalent aluminium particles are obtained, which are quite active when formed and participate in the process of nitrates reduction.

However, the increase of reduction of $\mathrm{NO}_{3}{ }^{-}$and $\mathrm{NO}_{2}{ }^{-}$occurs only till the optimal value of current density is reached. At a further increase of current density, the effect of $\mathrm{NO}_{3}^{-}$reduction decreases, due to the increase of the anode potential. Therefore, at high values of anode potential, the elimination of oxygen due to water decomposition occurs concomitantly with electrochemical dissolving of aluminium. It was found that in the pre-anodic zone, the reduction of nitrites to free nitrogen or inferior nitrogen oxides occurs concomitantly with the reaction of reduction of nitrite and nitrates.

In 2006 in the frames of the Redox-catalysis laboratory, investigations related to treatment of waste waters containing textile colorants are continuously performed (Gh. Duca, M. Gonța, V. Matveevici and V. Iambarțev).

Textile industry is one of the most polluting industries, due to high amounts of waste waters evacuated into the environment. The mean value of chemical dose of oxygen $(\mathrm{CDO})$ and of biochemical dose of oxygen $\left(\mathrm{BDO}_{5}\right)$ is in the range $11700-250 \mathrm{mg} \mathrm{O} / \mathrm{L}$ and $3500-100 \mathrm{mg} \mathrm{O}_{2} / \mathrm{L}$. Treatment of such waste waters is quite difficult. Traditional methods 
for treatment of textile waste waters are inefficient, due to the large variety of these compounds in waste waters, as well as to their high concentrations. Destructive methods are far more efficient, when as a result of oxidation or reduction of dyes molecules, products are formed with smaller molecular weights, which may be adsorbed on activated carbons, or eliminated by a continuous oxidation at biological treatment stations.

Therefore, we initiated the study of the process of diminution of textile (direct and active) colorants concentrations from model solutions, during their combined treatment with aluminium coagulant and catalytic oxidation of dyes using hydrogen peroxide. The process was investigated as function of: coagulant amount, initial dyes concentration, treatment time, oxidant concentration.

As a result of scientific investigations, the conditions of waste waters treatment were optimized. It was found that the effect of diminution of direct dyes concentration at treatment of solutions with coagulants was $94-96 \%$, and most efficiently direct dyes were eliminated from solutions with initial concentration of $200 \mathrm{mg} / \mathrm{L}$ and higher, which are characteristic to textile waste waters. However, it was demonstrated that a two-stage treatment of waste waters is more efficient. At first, it is necessary to decrease the concentration of direct dyes down to 8-12 $\mathrm{mg} / \mathrm{L}$ during the first stage, and then to decrease it further during the second treatment stage (until the admissible concentration for evacuation in water reservoirs is reached) by adsorption of activated carbons, of by catalytic oxidation with hydrogen peroxide in the presence of iron(II) ions. In the case of optimal combination of coagulation with catalytic oxidation using hydrogen peroxide, the effect of diminution of direct dyes from model solutions with initial concentrations of $200 \mathrm{mg} / \mathrm{L}$ increases up to $97-98 \%$, while the amount of coagulant and formed sediment decreases two folds. The method of catalytic oxidation has advantages, as compared to that of adsorption on activated carbons, as it leads to an advanced degradation and mineralization of organic dyes molecules, forming simple nontoxic compounds such as carbon dioxide and water, and some simple organic compounds, such as aldehydes, organic acids etc., which are already biodegradable.

Utilization of the catalytic oxidation method alone leads to the degradation and mineralization of direct colorants only from model solutions and waste waters with a low content of these dyes ( $50 \mathrm{mg} / \mathrm{L}$ at most).

In the case of active dyes, utilization of the coagulation method during the first treatment stage is inefficient (only $10-15 \%$ of the initial dye amount is eliminated using aluminium coagulants). Therefore, the oxidation method using hydrogen peroxide is applied in order to achieve a more significant decrease of dyes concentration in model solutions and waste waters. Results showed that using hydrogen peroxide in model solutions with initial concentrations of around 150-160 mg/L leads to an oxidation and mineralization effect of 78-84\%. Remaining concentration of formed compounds may be decreased to that admissible by activated carbon adsorption. This treatment method allows the diminution of active dyes concentration from model solution in the case when iron(II) ions are used as catalysts. If ultraviolet irradiation is used to catalyze this process, the effect of oxidation and mineralization of dyes remains the same for dyes concentration of $50 \mathrm{mg} / \mathrm{L}$. If the dye concentration increases, the effect of hydrogen peroxide oxidation at presence of UV irradiation decreases and the process becomes inefficient.

It is widely known that grape processing generates around $20 \%$ of wastes, which pollute the environment. However, these secondary winery products may be used to obtain various valuable compounds. Therefore, researchers of the department initiated scientific investigations in the field of optimization of the process of obtaining of reductons from secondary winery products (Gh. Duca, M. Gonța, A. Mereuța, I. Guțu and N. Marchitan). Scientific results led to the elaboration of a new, easier procedure of obtaining tartaric acid, which broadens the field of utilization of raw material, which contains tartaric compounds, increases the final product purity, assures a reduced consumption of chemical reagents and contains two know-how elements [13]. As opposed to the classical procedure, the proposed technology excludes the stage of calcium tartrate obtaining, due to the application of reactive extraction, which allows performing a selective extraction of tartaric acid from the aqueous solution using an extragent, such as th anionic resin "Amberlite LA-2" dissolved in an organic solvent - butyl acetate, which allows increasing the output and the purity of the final product. The crystallization of tartaric acid from the azeotrope mixture, which is formed when an organic solvent (in which tartaric acid is almost insoluble) is introduced into the water solution, is performed at the same time with the distillation of water from the mixture, thus decreasing the crystallization time, and increasing the purity rate. Installations of extraction, crystallization and drying of TA were elaborated. The pilot installation for the production of tartaric acid was mounted, and the technological regulation of production of tartaric acid from calcium tartrate was elaborated. Technical prescriptions were approved for the tartaric raw material (calcium tartrate, calcaric sediments, etc.); technical prescriptions for the final product (tartaric acid) were also elaborated.

Procedures of obtaining dialkyl tartrates, sodium dihydroxyfumarate [12] and dimethyl dihydroxyfumarate were elaborated; these compounds are important reductons suggested for utilization in the cosmetic industry. Cosmetic creams were obtained on the basis of diethyl tartrate and their reological properties were compared to the blank, according to the following parameters: viscosity, adhesion, shear tension; the compatibility of diethyl tartrate with the basic raw material was assessed, and it was demonstrated that this preparation cab be used for the production of cosmetic creams. On the basis of obtained experimental data, it was shown that substitution of lanoline with diethyl tartrate may be considered an admissible procedure, and that the diethyl tartrate containing cream is more stable in time than the lanoline containing cream. 
The processes of extraction of tartaric acid from winery wastes were optimized, using solid anionites impregnated with amines, using the tertiary amine - tri-n-octylamine and the secondary amine lauryl-trialkyl-methylamine. It was found that solid and liquid anionites of Amberlite type, exhibit the highest performance: 93-96\%. Tartaric acid was transformed into alkyl esters, and these were transformed into hydrazones and thiosemicarbazide derivatives. On the basis of tartaric acid dihydrazide, synthesized from dimethyl- or diethyl tartrate, the bishydrazones of salicylic acid and 5-nitrofurfurol were obtained. New bishydrazones of the 2-R-phenyl - 1,3-dioxolan - 4,5 - dicarboxylic acids and bis-thiosemicarbazides were synthesized. Synthesized compounds are potentially biologically active. Bis-hydrazones of salicylic acid and bis-thiosemicarbazide derivatives are of interest as complex formatting compounds with heavy metals.

Scientific laboratory „Electrochemical processes and clean technologies”(PhD O. Covaliov, V. Covaliov, V. Neno, V. Jalbă)

Researches in the frames of the laboratory of „Electrochemical processes and clean technologies” (1996-2008), address many scientific issues. One of the most significant problems for our country in this field is the cyanide pollution of waters. In order to solve this issue, a new economically advantageous procedure was elaborated, for the neutralization and utilization of wastes generated by the gelatine-tannin treatment of wines, which contain cyanide formed due to wines demetallyzation. This procedure is performed by separating the bentonite from the yeasts, using electroflotation and selective treatment of iron cyanides (Prussian blue) in alkaline medium, which gives micro fertilizers with nanodisperse structure and prolonged action, fungicide preparations, corrosion converters, new pigments and/or reagents for wines demetallyzation [24].

To produce the intensification of water treatment from persistent organic pollutants, new technical principles were elaborated for obtaining highly dispersed compounds of titanium oxides with nanostructural characteristics, by regulating their disperse phases and photocatalytic properties. New methods were elaborated for the deposition of multicomponent boron-containing catalytic layers on porous ceramic supports, and subsequent boron dissolving, for their concomitant utilization with nanodispersed metal oxides in the process of photocatalytic destruction of pollutants. A multi-functional electro-photocatalytic laboratory scale reactor was built, with high capacity of treatment and destruction of persistent organic pollutants of benzothiazol class [28].

Researchers studied the kinetic processes and the mechanism of photocatalytic transformations, in stages, of benzothiazol macromolecules, as well as of one derivative of benzothiazol, on the basis of modern physico-chemical methods. The following technical solutions were elaborated and tested on pilot scale, some of them with no analogues:

- new principle of treatment of waste waters containing sparingly biodegradable polyphenols using photocatalytic hydrolysis, and UV radiation, in order to improve the efficiency of the biochemical purification of water and the generated amount of biogas;

- new method of methanogenic synthesis of vitamin $B_{12}$ in the composition of sediments which are formed during anaerobic treatment of waste waters;

- method of concentration and purification of biogas-contained methane, for its more efficient utilization;

- technology for obtaining nanostructured micro-fertilizers on the basis of biologically active metals («metals of life») for their introduction into soil;

- construction of the biochemical reactor on the basis of standard vessels existent at factories, with an automated system of controlling anaerobic fermentation [27].

Also, scientist of this laboratory developed a technology of microbial degradation of cyanides from wastes generated by gelatine-tannin treating of wine, concomitantly with soil enrichment with elements important for plants nutrition. Thus, these compounds were first solubilised using the waste generated by sugar production, in order to accomplish a faster and more complete microbial degradation of these compounds. A technology of obtaining combined fertilizers in various doses was elaborated and tested. This method allowed increasing the productivity of green mass by 14,1-15,0 centners/ha [22].

Scientists of this laboratory also elaborated other methods for destroying wastes generated by the gelatine-tannin treatment of wine: the oxido-thermal method and the utilization of sediments as nitrogen fertilizers, for selecting and assuring the implementation of the most effective method of those mentioned above, to eliminate the environmental hazard and to assure a direct economical success [23].

As to the treatment of waste waters, the particularities of magneto-hydrodynamical conditions of pseudo fluidization of aquatic medium were studied, related to processes of destruction of organic compounds with concomitant action of UV radiation. The magnetic field influences the increase of the efficiency of destruction of organic compounds by an additional action on the molecular structure of organic compounds. It was found that the values of $\mathrm{CDO}$ and $\mathrm{CDO}_{5}$ of treated water decreases from $835 \mathrm{mg} \mathrm{O}_{2} / \mathrm{L}$ and $378 \mathrm{mg} \mathrm{O}_{2} / \mathrm{L}$ to $108 \mathrm{mg} \mathrm{O}_{2} / \mathrm{L}$ and $37 \mathrm{mg} \mathrm{O}_{2} / \mathrm{L}$, respectively. At the same time, occurs the destruction of molecules of magnesium and calcium carbonates and bicarbonates, which determine water hardness. It was determined that the hardness of the water treated in such a way, decreases from $6,72 \mathrm{mg} \cdot \mathrm{equiv} / \mathrm{L}$ to $3,8 \mathrm{mg} \cdot$ equiv/L. The energy used on the account of UV irradiation constitutes $0,01-0,03 \mathrm{~kW} \cdot \mathrm{h} / \mathrm{m}^{3}$. The bacteriological 
action of UV light on water is exhibited by the formation of peroxides $\left(\mathrm{H}_{2} \mathrm{O}_{2}\right)$, ozone $\mathrm{O}_{3}$, as well as of active radicals, such as $\mathrm{O}^{2-}, \mathrm{HO}_{2}^{-}$etc. [21].

The influence of the anodic material on phenolic compounds transformation was studied, in conditions of electrochemical generation of active chlorine. The investigation of the process of electrogeneration of active chlorine, including $\mathrm{NaClO}, \mathrm{NaClO}_{3}$ and dissolved $\mathrm{Cl}_{2}$, using broad graphite electrodes, showed that when the current intensity

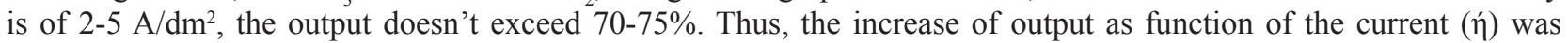
performed up to $93-95 \%$, but the process occurred with the increase of hydraulic resistance. In order to eliminate this phenomenon, a new method of electrogeneration of active chlorine was suggested, where magnetite particles were introduced in a permanent magnetic field, formed by spherical particles of barium hexaferrite [5].

Scientists performed investigations regarding galvanochemical processes of production of aluminium containing coagulants. The mechanism of this process, which occurs on the account of internal electrolysis of the galvanic pair aluminium-carbon, was studied. The standard potentials of aluminium and caked coal are equal to $\varphi_{0}{ }^{\mathrm{Al}}=-1,662 \mathrm{~V}$ and $\varphi_{0}{ }^{\mathrm{C}}=+0,792 \mathrm{~V}$, respectively, thus $\Delta \varphi \approx 2 \mathrm{~V}$. This significant difference between potentials allows creating conditions when, during the contact of these materials, aluminium transforms into the anode and decomposes quite fast: $\mathrm{Al}^{0}-3 \mathrm{e}^{-} \rightarrow \mathrm{Al}^{3+}$. In the case of graphite, water electrolysis is possible, with oxygen involvement, giving hydroxide ions $(\mathrm{OH}):$ $\mathrm{H}_{2} \mathrm{O}+1 / 2 \mathrm{O}-2 \mathrm{e} \rightarrow 2 \mathrm{OH}^{-}$which hydrolyze the $\mathrm{Al}^{1+}$ ions, forming intermediate complexes such as $[\mathrm{Al}(\mathrm{OH})]^{2+} \rightarrow\left[\mathrm{Al}(\mathrm{OH})_{2}\right]^{+}$ etc. In the presence of chlorine or fluorine ions, aluminium hydroxychloride is formed, with the general formula $\mathrm{Al}_{2}(\mathrm{OH})_{\mathrm{n}} \mathrm{Cl}_{6-\mathrm{n}}$, known as an active coagulant. Coagulation characteristics of synthesized aluminium hydroxychloride were studied, and 6-8 fold increased efficiency was discovered, as compared to coagulation properties of aluminium sulphate, currently used in practices [26].

Many of the realizations achieved in the laboratory of Electrochemical processes and clean technologies were implemented, such as the technology of production of biogas - implemented at the winemaking factory Vinăria Bardar, which is an automated, semi-industrial installation for biogas production with a $35 \mathrm{~m}^{3}$ capacity. Currently, the technology of detoxification of the sediment resulted during the gelatine-tannin treatment of wine is being implemented, as well as obtaining of new products, based on laboratory experimental installations.

\section{Laboratory of scientific research „Atmosphere protection” (acad. Gh. Duca, PhD A. Crăciun)}

Atmosphere protection is an important problem, and also a large area of investigation of ecological chemistry. Since 1996, researchers of the laboratory performed a series of investigations in order to diminish toxic emissions into the atmosphere during the activity of thermo-energetic aggregates and internal combustion motors:

- hydrogenation during combustion of hydrocarbon fuel;

- investigation of combustion of naphtha-water emulsion;

- investigation of combustion of natural gas using catalysts;

- utilization of electrical field to influence the flame during natural bas combustion;

- influence of the homogeneous catalyst on the efficiency of gasoline and diesel combustion.

A scientific project was accomplished in the frameworks of the laboratory, regarding the elaboration and investigation of high efficiency, environmentally clean plastic lubricant materials, on the basis of regenerable material - colza seed oil.

Also, applicative elaborations and investigations were performed, such as: hydrogenation during the combustion of hydrocarbonic fuel; investigation of combustion of naphtha-water emulsion and elaboration of installations for obtaining of naphtha-water emulsion. Combustion of this emulsion reduces the naphtha consumption by $10-12 \%$, while atmospheric emissions are lower than admissible concentrations [17].

In order to perform the study of catalytic natural gas combustion, were elaborated the composition and technology of catalyst deposition of ceramic cell-type blocks, which are subsequently used in burners for natural gas burning.

The mixture gas-air is bubbled through catalytic layers, deposited on cell-type ceramics, and then burned. As a result of catalyst utilization, atmospheric emissions of carbon monoxide decreased 1,8 - 1,9 fold, and of nitrogen oxides $-1,6-2,5$ fold [18].

Investigations related to the influence of the homogeneous catalyst on the efficiency of burning of gasoline and diesel, in internal combustion motors, were conducted using the catalyst "BIO-friendly" (SUA). As a result of these researches, it was established that environmental reduction of exhaust gases concentrations $1.5-1.9$ fold in the case of diesel motors, leads to the diminution of grime content, which is a carrier of carcinogenic aromatic hydrocarbons. Due to its high efficiency (1,4-2,0 fold decrease of $\mathrm{CO}$ concentrations in exhaust gases, $\mathrm{CH}-1,5-1,7$ fold, $\mathrm{NO}_{x}-1,3-1,6$ fold, as well as reduction of gasoline consumption by $10 \%$, and of diesel by $15 \%$ and absence of carcinogenic and mutagenic substances in its composition), the homogenous catalyst may be recommended as an additive for gasoline and diesel [19].

Utilization of electric field in order to influence the flame of natural gas combustion allows obtaining the following effects: increase of the flame temperature from 1100 to $1190^{\circ} \mathrm{C}$; reduction of $\mathrm{CO}$ concentration in burned gases from $1,2 \%$ to $116 \mathrm{ppm}(0,12 \%)$. Utilization of this technology leads to a $5 \%$ saving of fuel [20]. 
Elaborations and investigations of high efficiency environmentally clean plastic lubricant materials on the basis of regenerable material (colza seed oil) led to obtaining plastic polyfunctional lubricants: for articulations with equal angular rates; for cold deformation processing of metals; electroconducting, which outrank prototypes used in Russia, Ukraine and some European countries.

Conducted scientific studies allowed elaborating pilot installations for obtaining of naphtha-water emulsion, for catalytic burning of natural gas, for studies related to the influence of electrical field on the flame of natural gas burning, for production of four samples of plastic lubricants.

Research in the field of ecological chemistry started at the Institute of Chemistry the ASM at the beginning of the 70's, when the laboratory „Mineral resources and the chemistry of water” was created.

For over 30 years, water quality of main aquatic resources of the Rep. Moldova has been studied, such as rivers Danube, Nistru, Prut, Răut, Bâc, accumulation lakes Dubăsari, Costeşti-Stânca, Cuciurgan, Ghidighici, Taraclia, Ialpug, Cahul etc. The results of these researches allowed establishing of processes and mechanisms of interaction of chemical components in the aquatic resources, as function of many factors, such as: temperature, reaction medium, dissolved oxygen concentration, anthropic pressing, turbidity, water flow rate, ionic force etc. (V. Ropot, M. Sandu, R. Lozan, T. Lupascu, G. Stratulat, V. Rusu, I. Dranca et al.) [29].

Also, investigations were performed on the processes and mechanisms of immobilization, migration and transformation of heavy metals, organic and inorganic compounds of nitrogen and phosphorus in the system water matters, in suspensions - bottom depositions in the main aquatic resources of the Republic of Moldova (V. Rusu, T. Lupascu, L. Postolache) [30].

The obtained results formed the basis of evidencing the main laws of formation of natural waters quality, which are especially important for predicting water quality, theoretical ascertainment and implementation of surface waters potabilization technologies.

The quality of waste waters, generated by the main economical unities of the republic, was studied. The processes and mechanisms of coagulation, decantation, flotation, oxidation, adsorption of organic and inorganic pollutants, discovered in waste waters, on carbonic and mineral adsorbents, were investigated. The obtained results were used for the elaboration of technologies of purification of waste waters generated by agro-alimentary and textile factories. The most relevant results in this field are the elaborated technologies, which were implemented at the winemaking factory in Bălți, which allowed the purification of waste waters generated during wine distillation. Application of this technology allows obtaining tartaric acid and construction materials from the sediments formed after decantation of mineral adsorbents. A significant share of research in this field was performed under the direction of the regretted chemist and ecologist, Ph doctor in chemistry, Valeriu Ropot [31].

Another elaborated and implemented technology is the technology of treatment of waste waters generated at texture colouring sections of textile factories. Purified waste waters may be recycled into the technological process of texture colouring, thus saving potable water sources (T. Lupascu, M. Ciobanu, N. Timbaliuc) [32].

Provision of world population with high quality drinking water was always one of the most important goals to be achieved by humanity, from any point of view. This constitutes a significant problem for the Republic of Moldova, as well, considering that our country possesses limited amount of drinking water originating from surface and underground water sources.

Considering all stated above, the issue of elaboration of technologies for potabilization of surface and underground waters remains, as always, one of the main research objectives of the Ecological Chemistry laboratory of the Institute of Chemistry the ASM. During the years, research was performed in order to optimize the technologies of surface and underground waters potabilization. The chemical indices of water quality were studied following the treatment stages of the potabilization process of the Nistru and Prut waters. It was found that the currently applied technologies don't provide a high and stable quality of drinking water. Investigations showed that following the existent technological flux at potabilization stations, drinking water contains small amounts of organic compounds of chlorine, nitrogen and phosphorus. This leads to the conclusion that drinking waters contains small amounts of pesticides, trihalogenomethane etc.

The techniques leading to the enhancement of drinking water quality were studied, namely the substitution of the chlorination process with that of ozonation and the process of adsorption of persistent organic pollutants traces by their filtration on columns of activated carbons, obtained from fruit stones and nutshells. The obtained results demonstrated that the utilization of mentioned above processes allow obtaining high quality drinking water (V. Ropot, T. Lupascu, M. Nicolau) [33].

Underground waters of our republic play an important role in the provision of population and economical agents with drinking water, especially in rural zones. However, unfortunately, the analyses performed in order to establish the quality of underground waters evidenced that over 50 percent of these waters don't correspond to the standards of drinking water, and are characterized by an increased content of fixed residue, total hardness, fluorine, iron, ammonia, hydrogen sulphide, methane, chlorides, sulphates, nitrates, nitrites, manganese etc. 
The presence of hydrogen sulphide in underground waters used for provision of the population induces various affection of human health. According to sanitary standards set for drinking water, sulphide ions must be absent. Analysis of scientific literature shows that there are several techniques and technologies in the world, dealing with the purification of underground waters of hydrogen sulfide. The most frequently used is the method of oxidizing sulphide ions by aeration in the presence of solid supports, including activated carbons. The main disadvantage of this technology consists in the fact that it results in the formation of colloidal sulphur, which clogs up the pores of the adsorbents, thus diminishing its catalytic activity. Also, heavy colloidal sulphur is hard to be removed through decantation and filtration.

During the last 15 years, the laboratory of Ecological Chemistry of the Institute of Chemistry the ASM deals with scientific research regarding the technologies of purification of underground waters from hydrogen sulphide and its salts. The analysis of gathered data allowed evidencing and selecting a catalyst based on activated carbons obtained from peach stones, with copper ions impregnated on its surface.

Utilization of mentioned above catalyst allows oxidizing the sulphur ions into thiosulphates, sulphates, sulphites, thus avoiding the formation of colloidal sulphur. This procedure is a global scale novelty, which was patented (R. Nastas, T. Lupascu, V. Rusu, M. Tcaci, Gh. Duca) [34]. At present, the scientist of the laboratory carry out scientific research which would allow obtaining catalyst that would oxidize sulphur ions in sulphate, avoiding the stages forming intermediate compounds. These investigations are performed in the frames of the project entitled „Optimization of technological processes of potabilization of surface and underground waters” which is part of the State Program entitled „Scientific and management research of water quality”, headed by academician Gh. Duca. Sustainable economical and social development without the determination of environmental quality enforces an adequate waste management, without exhaustion of natural resources.

One very acute problem of ecological chemistry consists in rational valorisation of secondary products derived from grapes and fruit processing. In the Republic of Moldova, as the result of grapes processing, dozens of thousands of tons of grape seeds are obtained, which contain up to $16 \%$ oils, $14 \%$ tannins and other precious products.

Processing of peaches, plums, apricots, also results in thousands of tons of stones, which contain up to $5-7 \%$ oil. Nutshells are obtained, as well, in amounts of hundreds of tones following the separation of nutmeat. All these are valuable raw materials for various valuable products necessary for the national economy.

During last 20 years, the scientists of the laboratory of Ecological Chemistry perform scientific research in order to elaborate technologies for the production of activated carbons from fruit stones, grape seeds and nutshells. As a result of performed investigations, were elaborated and patented dozens of procedures of activated carbons production using physico-chemical, chemical and mixed activation methods. The structural parameters, adsorption capacity and surface chemistry of activated carbons were estimated. Obtained results demonstrated that quality indices of local activated carbons are superior, or at least equivalent to those imported. Obtained activated carbons were tested in order to establish the possibility of their utilization for treatment of surface, underground and waste waters, as well as for the detoxification of human body. It was found that these activated carbons are extremely fitted for solving issues of ecological chemistry, namely for the protection of the environment and human health. On the basis of mentioned scientific research, 3 theses of dr. hab. and 3 theses of Ph doctor were proved (T. Lupascu, R. Nastas, V. Botan, V. Goncear, V. Rusu, M. Tcaci, M. Ciobanu, O. Petuhov) [35].

As mentioned above, grape seeds contain increased tannins amounts, which represent a series of natural compounds with polyphenolic structure. The interest towards these compounds is due to their antioxidant properties, i.e. these compounds trap free radicals, thus protecting the human organism from various diseases, such as cancer and cerebral ictus. The majority of enotannins are soluble in ethylic alcohol and insoluble in water. This hindrances the utilization of enotannins in various field, including pharmaceutics. The specialists of Ecological Chemistry Laboratory elaborated and patented a procedure of hydrosolubilization of enotannins. Using the method of mass spectrometry, it was found that the procedure consists in breaking catechin polymers of enotannins. As the result of this procedure, a new product was obtained, formed from monomers, dimers, trimers of catechin, polydentate carboxylic acids, peroxidic compounds etc. Microbiological, pharmacological and toxicological investigations, performed in the frameworks of the project „New preparations from grape seeds for medicine, veterinary and agriculture” and „Evaluation of activity of medicinal and agricultural preparations obtained on the basis of the biologically active compound Enoxil in clinical and field trials” in the frames of the State Program „Processing and utilization of winery wastes and obtaining of new compounds" directed by acad. Gh. Duca, demonstrated that Enoxil is not toxic, and possesses significant antifungal and antibacterial properties. On the basis of the active compound Enoxil, the medicinal preparations Enoxil-M and Enoxil-A were elaborated and tested in clinical and field conditions. Field trials showed that the preparation Enoxil-A increases the resistance of agricultural cultures by $60 \%$ towards the action of root rot, and of vine - by two folds, towards grey rot (T. Lupascu, Gh. Duca, L. Lupascu, P. Vlad, R. Nastas, G. Lupascu, V. Rudic, V. Crivceanschi, V. Gonciar, V. Ciobanu etc.) [36]. 
Clinical trials of the medicinal preparations Enoxil-M produced at „Farmaco” enterprise demonstrated a positive effect in the treatment of diseases induced by fungi and bacteria, of plagues provoked by thermal and surgical lesions.

Researchers of the laboratory of Chemical Ecology have been preoccupied by the utilization of wastes generated at the calcite mines in the vicinity of Chişinău for almost 20 years. As a result of these studies, 5 compositions of construction materials, with calcite powder as the main component, were elaborated and patented. The obtained construction materials are $30 \%$ cheaper as compared to analogical imported materials, and are qualitatively equal to them. Industrial scale production of new construction materials is carried out at the „Monolit” enterprise in Chişinău (T. Lupascu, V. Botan, V. Ungureanu) [37].

Investigations of mineral resources of Republic of Moldova (diatomites, bentonites, tripoles etc.) started in 1962 in the frameworks of the laboratory of Mineral resources, as it was called then. In 1972, it was transformed into the laboratory of Mineral resources and chemistry of water. These investigations continue in the present, in the frames of the Ecological Chemistry laboratory, which is the successor of the laboratory of Mineral resources and chemistry of water since 1992. During these years were performed studies of physical, physico-chemical and chemical properties of intact mineral adsorbents, as well as of those modified through chemical and thermal procedures (M. Cherdivarenco, V. Ropot, V. Rusu, A. Moftuliac, G. Stratulat) [38].

Sorption and cationic exchange properties of intact and modified adsorbents were studied. Humic acids, fulvic and carboxylic acids, natural and synthetic colorants etc. were used as adsorbates. The following cations were studied: $\mathrm{Fe}(\mathrm{II}), \mathrm{Fe}(\mathrm{III}), \mathrm{Al}(\mathrm{III})$, and $\mathrm{Cu}(\mathrm{II})$. The obtained results were used in surface waters potabilization technologies and waste waters purification technologies.

During last several years, special procedures led to obtaining of a wide spectrum of oligomers of aluminium oxy-hydroxy complexes, with charges ranging from $\left[\mathrm{Al}_{2}(\mathrm{OH})_{2}\left(\mathrm{H}_{2} \mathrm{O}\right)_{8}\right]^{4+}$ to Keggin ion $\left[\mathrm{Al}_{13} \mathrm{O}_{4}(\mathrm{OH})_{24}\left(\mathrm{H}_{2} \mathrm{O}\right)_{12}\right]^{7+}$. These oligomers possess properties of molecular sieves with pores bigger than of common zeolites, and a wide range of practical utility (V. Rusu, L. Postolache).

The continuous increase of the mean atmospheric temperature in immediate soil proximity, as well as of sea and ocean waters represents a universally accepted statement during last decades.

The mean air temperature in the vicinity of Earth surface increased by $0,74 \pm 0,18^{\circ} \mathrm{C}$ during the last century. Global warming has a negative impact in various fields. Due to this phenomenon, glaciers and snow melt, leading to the increase of sea level, and "swallowing" by water of new soil surfaces, which are already insufficient for a proper food provision of the world population.

Temperature increase will lead to the migration of deserts towards more dump areas and, respectively, to the disturbance of the ecological equilibrium, established for thousands of years, including in the world of plants and animals species. Evidently, as a result of these changes, the physical and psychical state of man will be altered.

In order to diminish the negative effects of global warming, scientist seek new alternative sources of energy. Solar energy is the most perspective, and may be used in many different ways. The oldest and most common method is obtaining of biomass during photosynthesis. Mankind always used wood as an energy source. From the point of view of carbon cycle, this energy is environmental friendly, because plants developed using atmospheric carbon dioxide, and it is again emitted during plants burning, and again absorbed during photosynthesis. Biomass may be also used as raw material for obtaining biogas through chemical methods of anaerobic fermentation, and of biodiesel, bioethanol through chemical procedures and aerobic fermentations.

One of the global problems to be solved by mankind is obtaining hydrogen from water using solar energy. In order to solve this issue, billions of dollars and euro are currently spent. As a result, hydrogen will become one of the main "green" energy sources, necessary for mankind existence. Of course, today fundamental investigations are carried out in this field, in order to solve the problems of optimization of photolysis processes using various nanocatalysts, depositing, transportation and utilization of hydrogen.

Recently, such investigations were initiated at the Centre of Physical Chemistry and Nanocomposites at the Institute of Chemistry the ASM, directed by acad. Gh. Duca. We are confident in the future results of our scientists in this area.

\section{References}

[1]. Gh. Duca, Cr. Zanoagă, M.Duca, V. Gladchi. Procese redox în mediul ambiant. - Chişinău: CE USM, 2001. - 382 p.

[2]. Duca Gheorghe, Scurlatov Yurii. Ecological chemistry. Chisinau: Publishing Center MSU, 2002, 289p.

[3]. Gh. Duca, V. Gladchi, L. Romanciuc. Procese de poluare şi autoepurare a apelor naturale. Chişinău, CEP US.

[4]. Сычев А.Я., Травин С.О., Дука Г.Г., Скурлатов Ю.И. Каталитические реакции и охрана окружающей среды. - Кишинев: Штиинца, 1983. - 271 с. 
[5]. Скурлатов Ю.И., Дука Г.Г. Химия и жизнь воды.- Кишинев: Картя Молдовеняскэ, 1989. - 126 с.

[6]. Gladchi V., Goreaceva N., Duca Gh., Bunduchi E., Romanciuc L., Mardari I., Borodaev R. The Study of Redox Conditions in the Dniester River. Chemistry Journal of Moldova, 2008, vol. 3, no.1, p 70-76.

[7]. Duca Gh, Bunduchi E., Gladchi V., Romanciuc L., Goreaceva N. Estimation of the Natural Water SelfPurification capacity from the Kinetic Standpoint. Chemistry Journal of Moldova, 2008, vol. 3, no.1, p 10-21.

[8]. Bunduchi E., Duca Gh., Gladchi V., Goreaceva N., Mardari I. Assessment of kinetic parameters in the water of the Nistru course in the section Naslavcea-Dubasari. Chemistry Jornal of Moldova, volume 1, N 1, 2006 , pp. $68-73$.

[9]. Gonța M. The role of the natural antioxidants in the oxihaemoglobin oxidation and the diminution of the nitrit concentration.//Chemistry journal of Moldova,2007,Nr.1, p.67-77.

[10]. Gonta Maria Gheorghe Duca, Diana Porubin ,Establishment of the antioxidant/antiradical activity of the inhibitors using the DPPH - radical Chemistry journal of Moldova, 2008, V.3, No.1, p.118-126.

[11]. Duca Gh., Gonta M., Matveevici V., Iambartev V. The mechanism of nitrates transformation in the processes of electrochemical treatment of natural waters. //Environmental Engineering and Management Journal, 2002, vol.1,No.3, p. 341-346.

[12]. Duca Gh., Gonța M., Oniscu C., Mereuța A., Cojocaru C. Mathematical optimisation of synthesis process of dihydroxyfumarate acid sodium salt.//Roumanian Biothechnological, 2002, vol. 7, nr. 5, România, p. 897-904.

[13]. Duca Gh., Gonța M., Mereuta A., Cojocaru C. Production of tartaric acid from wine yeast via reactive extraction.// Enviromental Engineering and Management Journal, September, 2004, Vol.3 ,No.4, p. 771-780.

[14]. Mirvish S.S., Gonța M., Stepanov I., Hecht S.S., Comparative analyzis of tabacco-specific itrosamines and total N-nitroso compounds in moldovan cigarette tobacco. //Journal of Agricultural and Food Chemistry, 2005,53, N20, p.8082-8086.

[15]. Simonov Y.A., Gonța M., Yavolovskii A.A. 11-Nitroso-6,7,10,11,12,13,15,16-octahydro-9H-5,8,14,17 -tetraoxa-11- azabenzocyclopentadecene.//Acta Cryst, E61,2005, 2005, p. 03136 - 03139.

[16]. Porubin Diana, Hecht Stephen S., Li Zhong-ze, Gonta Maria, and Stepanov Irina, Endogenous Formation of N- Nitrosonornicotine in F344 rats in the presence of some antioxidants and grape seed extract, Journal of Agricultural and Food Chemistry, 2007,Vol.55, Num. 17, p.7199-7204.

[17]. Sajin, T., Craciun, Al., Aniței, F., Buzduga, R. St. Air pollutants removal at burning of water-fuel emulsions and suspensions. România. Bacău. Revista "Modelling and Optimization in the Machines Building Field”.MOCM 14, 2008, p.253-258.

[18]. Gh.Duca, Al.Craciun, T.Sajin, A.Gaba, L.Păunescu. Tehnologii moderne de ardere şi de reducere a emisiilor poluante în atmosferă. Chişinău, 2002. CE al USM. -223 p.

[19]. Gh.Duca, T.Sajin, Al.Craciun, Ig.Mardari. Poluarea şi protecţia atmosferei. Chişinău, 2003. CE al USM. $212 \mathrm{p}$.

[20]. L.Păunescu, Gh.Duca, A.Gaba,T.Sajin,Al.Craciun,G.Surugiu. Utilizarea câmpului electric în procesul de ardere a gazului natural. "Mediul ambiant” №1, 2008. p.1-6.

[21]. Covaliov V., Covaliova O. "Aspecte teoretice şi practice de tratare electrochimică a apei” (în limba rusă) Ch.: CE USM. Chişinău 2004, - 432 p.

[22]. Covaliov V. "Ecologia industrială şi inovațiile” AGEPI, Chişinău, 2004, -132 p.

[23]. Gh. Duca, B.Gaina, O.Covaliova, V.Covaliov, M.Gonța "Ecologia pură în industria enologică” Chişinău: Ştiința, 2004, -420 p.

[24]. Ковалев В.В., Ковалева О.В., Дука Г.Г., Гаина Б.С. Основы процессов обезвреживания вредных отходов виноделия Кишинэу: Типогр. АНМ, 2007, -370с.

[25]. Ковалева О.В. Технология и экологическая безопасность гальванотехники. Учебно-методическое и справочное пособие. Кишинэу: CE3 al USM, 2007, -372 с.

[26]. Duca Gh., Covaliova O., Covaliov V. Auditul ecologic. Chisinau: Searec-com.srl. 2001. -294 p.

[27]. V. Covaliov, V. Jalba, Gh. Duca, O. Covaliova. Photocatalytic hydrolysis of sparingly biochemically degradable organic ingredients during treatment of waste waters containing fermentation products, Rev.Ştiințifică "Studia Universitatis" nr.2(12),Ser. Şt.ale Naturii, 2008, c.200-206.

[28]. Covaliova O., Electrochemical behaviour of chrome (VI) complexes in low concentration solutions, "Studiul Universitatis" nr.4, 2008.

[29]. Ропот В.М., Стратулат Г.В., Санду М.А., Лупашку Ф.Г., и др. Проблемы качества, использования и охраны водных ресурсов ССР Молдова, Кишинёв “Штиинца”, 1991, 285с.

[30]. V.Rusu, T. Lupascu, Chimia sedimentelor sistemelor acvatice. Proprietăți de suprafață. Modele fizico-chimice. Chişinău, ElenaV.I., 2004, 272 p.

[31]. Институт химии А.Н. МССР, под редакции П.Ф. Влад, Кишинев, Штиинца, 146с.

[32]. T.Lupaşcu. Cărbuni activi din materii prime vegetale. Chişinău, Î.E.P. Ştiinţa, 2004, 224 p. 
[33]. Ropot V., Nicolau Margareta, Curcăneanu N. etc. Studii privind calitatea apei r. Prut. Buletinul AŞ RM, seria biologie şi chimie, (1994), Nr.6, p. 41-46.

[34]. T. Lupascu, Raisa. Nastas, M. Ciobanu, Tatiana Arapu, V. Rusu. Removal of Hydrogen Sulphide ,Ammonia and Nitrite Ions from Water Solution Using Modified Active Carbons. Ecilogical Chemistry Inter. Conf. 20-21 mai 2005. Latest Advanses p.176-183.

[35]. M.Mercedes Maroto-Valer, Ion Dranca, Tudor Lupascu, Raisa Nastas. Efect of adsorbate polarity on thermodesorption profiles from oxidized and metal-impregnated activated carbons. Cabon 42 (2004) 2655-2659.

[36]. Gh. Duca, T.Lupaşcu, P.Vlad, V. Kulciţki, R.Nastas. Studies on the water Solubiliztion Processes of Oenotannins and their Pisico-chemical Properties. Chemistry Journal of Moldova. General, Industrial and Ecological Chemistry. V. 1, Nr. 1, 2006, p. 74-79.

[37]. Lupascu T., Botan V. Amestecuri de tencuire pe baza de ciment. B.I. nr. 3536.

[38]. Vasile Rusu, Larisa Postolachi, Tudor Lupascu. Phosphorus Content in water, Particulate Materials and Sediments of river Prut. Enviromental Enginering and Management Journal, p.591-596. 